\title{
Bulgaria and the Istanbul Convention - Law, Politics and Propaganda vs. the Rights of Victims of Gender-based Violence
}

\author{
Miriana Ilcheva ${ }^{1}$ \\ South-West University "Neofit Rilski”, Blagoevgrad, BULGARIA \\ Faculty of Law and History \\ Center for the Study of Democracy, Sofia, BULGARIA \\ Senior Analyst, Law Program
}

Received: 2 March 2020 • Accepted: 18 May 2020 - Published Online: 30 May 2020

Abstract

The following article deals with the debate among institutions, victim support NGOs and various religiously affiliated entities protecting "family values", as regards the ratification by Bulgaria of the Council of Europe Convention on preventing and combating violence against women (Istanbul Convention). The debate was deeply influenced by an active campaign against the document, which was ultimately declared by the country's Constitutional Court unconstitutional. The article then examines the long-lasting consequences of the campaign, having led to the rejection of several other key victim protection documents and to the overall undermining of the protection of victims of gender-based violence in Bulgaria.

Keywords: Istanbul Convention, debate, Constitutional Court, victim protection.

\section{Introduction}

Bulgaria signed the Council of Europe Convention on preventing and combating violence against women (Istanbul Convention) on 21 April $2016^{2}$ as part of its chairing the Committee of Ministers of the Council of Europe. It became the $40^{\text {th }}$ member state of the Council of Europe to sign the document. The move earned the praise of human rights and victim protection NGOs as the country pledged to prevent and counter all forms of gender-based violence. 3 Political

\footnotetext{
${ }^{1} \mathrm{PhD}$ candidate at the Faculty of Law and History, Blagoevgrad, and employed as Senior Analyst in the Center for the Study of Democracy, Sofia, BULGARIA.

${ }^{2}$ Council of Europe (2016). Bulgaria signs the Istanbul Convention. Retrieved 27 February 2020, from https://www.coe.int/en/web/istanbul-convention/newsroom/Lasset publisher/anlInZ5mw6yX/content/bulgaria-signs-the-istanbul-convention?inheritRedirect=false. 3 See, for example, Bulgarian Gender Research Foundation (2016). Bulgaria signed the Council of Europe Convention on preventing and combating violence against women and domestic violence (Istanbul Convention) (България подписа Конвенцията на Съвета на Европа за превенция и борба с насилието срещу жени и домашното насилие (Истанбулската конвенция)). Retrieved 27 February 2020, from

(C) Authors. Terms and conditions of Creative Commons Attribution 4.0 International (CC BY 4.0) apply. Correspondence: Miriana Ilcheva, South-West University "Neofit Rilski", Faculty of Law and History, Blagoevgrad, BULGARIA. E-mail: miriana@abv.bg.
} 
will to ratify the Convention was profusely expressed by various officials on different occasions 4 and at the beginning of 2018 the Council of Ministers officially proposed to the National Assembly to ratify the document. Already at this stage, it noted that the ratification would require amendments not only in the victims protection legislation, but also in norms of the Criminal Code, concerning gender-based violence, therefore such amendments were being prepared in relevant criminal and also civil legislation. ${ }^{5}$ However, around the same time a wide propaganda-inspired campaign ensued on the topic of ratification, resulting, among others, in a heated public discussion organized by the Speaker of the Bulgarian Parliament. ${ }^{6}$ In February 201875 MPs from the then ruling party seized the Constitutional Court on the constitutionality of the Convention and in July 2018 it was pronounced unconstitutional.7 Thus, the ratification was effectively barred and the only option before the country to counter gender-based violence remained to adopt its own, not Convention-based legislative amendments, which, as will be shown in Section 3.4., it did rather fragmentarily. Most recently, the European Parliament urged the six Member States (and the UK) not having ratified the document to do so without delay. ${ }^{8}$ However, Bulgaria sustained its position by adopting a negative opinion ${ }^{9}$ on the absence of mutual agreement between all the Member

http://bgrf.org/articles/\%Do\%B1\%D1\%8A\%Do\%BB\%Do\%B3\%Do\%Bo\%D1\%80\%Do\%B8\%D1\%8F\%Do\%BF\%Do\%BE\%Do\%B4\%Do\%BF\%Do\%B8\%D1\%81\%Do\%Bo-

\%Do\%BA\%Do\%BE\%Do\%BD\%Do\%B2\%Do\%B5\%Do\%BD\%D1\%86\%Do\%B8\%D1\%8F\%D1\%82\%Do\%Bo-

\%Do\%BD\%Do\%Bo-\%D1\%81\%D1\%8A\%Do\%B2\%Do\%B5\%D1\%82\%Do\%Bo-\%Do\%BD\%Do\%Bo-

\%Do\%B5\%Do\%B2\%D1\%80\%Do\%BE\%Do\%BF\%Do\%Bo-\%Do\%B7\%Do\%Bo-

\%Do\%BF\%D1\%80\%Do\%B5\%Do\%B2\%Do\%B5\%Do\%BD\%D1\%86\%Do\%B8\%D1\%8F-\%Do\%B8-

\%Do\%B1\%Do\%BE\%D1\%80\%Do\%B1\%Do\%Bo-\%D1\%81-

\%Do\%BD\%Do\%Bo\%D1\%81\%Do\%B8\%Do\%BB\%Do\%B8\%Do\%B5\%D1\%82\%Do\%BE-

\%D1\%81\%D1\%80\%Do\%B5\%D1\%89\%D1\%83-\%Do\%B6\%Do\%B5\%Do\%BD\%Do\%B8-\%Do\%B8-

\%Do\%B4\%Do\%BE\%Do\%BC\%Do\%Bo\%D1\%88\%Do\%BD\%Do\%BE\%D1\%82\%Do\%BE-

\%Do\%BD\%Do\%Bo\%D1\%81\%Do\%B8\%Do\%BB\%Do\%B8\%Do\%B5-

\%Do\%B8\%D1\%81\%D1\%82\%Do\%Bo\%Do\%BD\%Do\%B1\%D1\%83\%Do\%BB\%D1\%81\%Do\%BA\%Do\%Bo\%

D1\%82\%Do\%Bo-\%Do\%BA\%Do\%BE\%Do\%BD\%Do\%B2\%Do\%B5\%Do\%BD\%D1\%86\%Do\%B8\%D1\%8F-

507.

4 See, for example, Ministry of Justice of the Republic of Bulgaria (2017). Deputy Minister Ahladova: Bulgaria is going to ratify the Istanbul Convention (Зам.-министър Ахладова: България ще ратифицира Истанбулската конвенция). Retrieved on 27 February 2020, from https://webcache.googleusercontent.com/search?q=cache:cvGgejfLNpEJ:https://justice.government.bg/ $\underline{117 / 13759 /+\& c d=1 \& h l=e n \& c t=c l n k \& g l=b g}$.

5 Council of Ministers of the Republic of Bulgaria (2018). Agenda of the Council of Ministers session of 3 Jапиату 2018 (Дневен ред на заседанието на Министерския съвет на 03.01.2018 г.). Retrieved on 27 February 2020, from https://government.bg/bg/prestsentar/zasedaniya-na-ms/dneven-red-nazasedanieto-na-ministerskiya-savet-na-03-01-2018-g.

${ }^{6}$ National Assembly of the Republic of Bulgaria (2018). Public discussion on the Draft Law on the Ratification of the Council of Europe Convention on preventing and combating violence against women and domestic violence (Обществена дискусия по Законопроекта за ратифициране на Конвенцията на Съвета на Европа за превенция и борба с насилието наджени и домашното насилие). Retrieved on 27 February 2020, from https://parliament.bg/bg/discussion.

7 Constitutional Court of the Republic of Bulgaria (2018). Decision No 13, Sofia, 27 July 2018, promulgated SG issue 65/7 August 2018 (Решение № 13, София, 27 юли 2018 г., (обн., ДВ, бр. 65 от о7.08.2018 г.)). Retrieved on 27 February 2020, from http://constcourt.bg/bg/Acts/GetHtmlContent/f278a156-9d25412d-a064-6ffd6f997310.

8 European Parliament (2019). EU accession to the Istanbul Convention and other measures to combat gender-based violence. Retrieved on 27 February 2020, from https://www.europarl.europa.eu/doceo/document/TA-9-2019-0080_EN.html.

9 Council of Ministers of the Republic of Bulgaria (2019). Agenda of the Council of Ministers session of 11 December 2019 (Дневен редна заседанието на Министерския съвет на 11.12.2019 2.). Retrieved on 27 
States concerning their consent to be bound by that convention, regarding the Request for an opinion submitted by the European Parliament pursuant to Article 218(11) TFEU to the Court of Justice of the European Union. ${ }^{10}$ It thus allegedly barred the implementation of the Convention by the whole Union. The following article aims to firstly outline the legal and socio-political arguments by which the norms of the document were effectively rejected, which recurred at different stages of the campaign against it and, relatively uncritically, in the decision of the Constitutional Court. The (yet unsuccessful) efforts of institutions, human rights and victim support NGOs in favor of the document will also be shortly noted. Then, an overview will be provided of the immediate and long-term consequences of rejecting the Convention against the background of the substantial difficulties Bulgaria faces in protecting gender-based violence victims. As a result, the article will hopefully contribute to proving the (in)direct, yet visible, longterm detrimental effect the anti-Convention process has had on supporting this extremely vulnerable group of victims.

- A debate surrounded the ratification of the Istanbul Convention in Bulgaria.

- The Constitutional Court declared the Convention unconstitutional.

- The debate led to several subsequent campaigns against key documents.

- The process has had lasting consequences for protecting victims of violence.

\section{Methodology}

This article has relied on desk research of legislation, case law and various related statements by stakeholders, as well as public discussions on various acts. It also reflects the author's practical perspective as a think tank legal and policy analyst gathered throughout various events and personal meetings with interested actors.

3. National contradictions around an international treaty - Between law, politics and propaganda

\subsection{Arguments against the Istanbul Convention - Third sex and gender ideology}

Generally, the 2018 debate around the impending ratification of the Istanbul Convention by Bulgaria focused on whether the document indeed protected women against violence or simultaneously, as maintained by many, including a major political party, proclaimed a "third sex" and "gender ideology"."1

Early on in the societal contradiction, the public discussion organized by Bulgarian Parliament (see introduction), comprising short interventions by various stakeholders, succinctly

\footnotetext{
February 2020, from https://government.bg/bg/prestsentar/zasedaniya-na-ms/dneven-red-nazasedanieto-na-ministerskiya-savet-na-11-12-2019-g.

10 Court of Justice of the European Union (2019). Request for an opinion submitted by the European Parliament pursuant to Article 218(11) TFEU. Retrieved on 27 February, from http://curia.europa.eu/juris/document/document.jsf;jsessionid=2BC30754500BC2A3CFF3F47B03Do01 57 ?text $=\&$ docid $=221362 \&$ pageIndex $=0 \&$ doclang $=$ EN\&mode $=1$ st \&dir $=\& o c c=$ first \&part $=1 \&$ cid $=6150317$.

${ }^{11}$ Bulgarian Socialist Party (2018). Kornelia Ninova: When people say "No" to the Istanbul Convention, this chapter will be closed forever (Корнелия Нинова: Когато хората кажат "не" на Истанбулската конвенция, въпросът се затваря завинаги). Retrieved 28 February 2020, from http://bsp.bg/news/view/13815-

korneliya ninova kogato horata kajat ne na istanbulskata konventsiya vyprosyt se zatvarya zav inagi.html.
} 
indicated the leading counterarguments by religious denominations and NGOs of religious affiliation upholding "family values". Those were later developed into longer argumentative narratives via detailed opinions before the Parliament as part of the process to adopt the Convention's ratification law. ${ }^{12}$

First and foremost, a sociological line of argument was introduced. According to many, the document allegedly introduces the notion of "gender" which is different from "sex" and unknown to Bulgarian legal order, pursuing aims "different" from protecting women from violence and redefining the notions of sex; ${ }^{13}$ thus motivating people to choose their sex/gender themselves. ${ }^{14}$ As it will be shown in Section 3.2. and 3.3., the interplay between sex and gender proves the main bone of contention in the debate around the Convention and the decisive argument to pronounce it unconstitutional. Indeed, in their later opinions before the Parliament, religious denominations were worried about the new meaning of "sex", different from the generally accepted notion, and the expectation to "uproot" customs and traditions, based on traditional roles of men and women. Moreover, conceptual contradictions were allegedly partly due to incorrect translation of the original texts into the Bulgarian language. Therefore, according to the religious entity authoring one statement, the initial Bulgarian text should not be ratified, but corrected, wide public discussion should ensue and, in case the document is ultimately not ratified, amendments should be introduced to national legislation based on the consensual parts of the document. ${ }^{15}$

Further, from an allegedly human rights perspective, the Convention's norms concerning education on all levels about stereotyped gender roles are deemed to go against the idea of marriage between men and women, while family, according to the Universal Declaration of Human Rights, is the natural and fundamental group unit of society and is entitled to protection by society and the State. ${ }^{16}$ Such teachings would, according to some, effectively popularize a

${ }_{12}$ National Assembly of the Republic of Bulgaria (2018). Draft Law on the Ratification of the Council of Europe Convention on preventing and combating violence against women and domestic violence (Законопроект за ратифициране на Конвенцията на Съвета на Европа за превенция и борба с насилието над жени и домашното насилие). Retrieved on 28 February 2020, from https://parliament.bg/bg/bills/ID/77944/.

${ }_{13}$ See, for example, religious representatives' statements on National Assembly of the Republic of Bulgaria (2018). Public discussion on the Draft Law on the Ratification of the Council of Europe Convention on preventing and combating violence against women and domestic violence (Обществена дискусия по Законопроекта за ратифициране на Конвенцията на Съвета на Европа за превенция и борба с насилието над жени и домашното насилие). Retrieved on 27 February 2020, from https://parliament.bg/bg/discussion, p. 14-15, 17.

14 Ibid., p. 51.

15 See, for example, the opinion by the United Evangelical Churches. The opinion by the Seventh Day Adventist Churches Union also expressed worries about the sex/gender/sexual orientation/gender identity concepts interplay and deemed the definition of gender "subjective and insufficient". National Assembly of the Republic of Bulgaria (2018). Draft Law on the Ratification of the Council of Europe Convention on preventing and combating violence against women and domestic violence (Законопроект за ратифициране на Конвенцията на Съвета на Европа за превенция и борба с насилието над жени и домашното насилие). Retrieved on 28 February 2020, from https://parliament.bg/bg/bills/ID/77944/.

${ }^{16}$ See, for example, religious representatives' statements on National Assembly of the Republic of Bulgaria (2018). Public discussion on the Draft Law on the Ratification of the Council of Europe Convention on preventing and combating violence against women and domestic violence (Обществена дискусия по Законопроекта за ратифициране на Конвенцията на Съвета на Европа за превенция и борба с насилието над жени и домашното насилие). Retrieved on 27 February 2020, from https://parliament.bg/bg/discussion, p. 14-15, 64. 
"gender ideology" which is a type of "psychological violence" towards children. ${ }^{17}$ This argument is used repeatedly throughout the counter-Convention narrative and, although not given by the Constitutional Court, becomes the basis for further attacks against educational tools to counter gender-based violence (see Section 3.4.). To support this line, in its opinion before the Parliament, a religiously affiliated international lawyers' $\mathrm{NGO}^{18}$ mentioned that the efforts to change social and cultural models and introduce education on gender equality and non-stereotyped gender roles contradicted the primary role of parents in the raising and education of their children. As the document practically opposed major religious denomination teachings, it thus also violated the freedom of religion and the professional secrecy of confession due to the duty to report it introduced for various religious professionals.

Moreover, in an additional, more legalistic line of argument, it is claimed that violence does not only victimize women, but also children, as well as men and older people. ${ }^{19}$ There is allegedly sufficient national legislation, and international standards, ${ }^{20}$ to fulfil the aims of the Convention ${ }^{21}$ and what is possibly needed is only some additional criminalization of acts of violence in the Criminal Code. ${ }^{22}$ This argument seems to downplay the specifics of gender-based violence and, even when the need for some legislative amendments is admitted, refuses to acknowledge the deep sweeping reform the country needs to undertake in the protection of that category of victims. Following this legalistic line, the religiously affiliated, international lawyers' NGO just mentioned ${ }^{23}$ insisted there was sufficient legislation to meet the aims of the Convention. The Convention allegedly introduced ideological reformulations of traditional notions like sex, family, men and women, codifying the contradictory notion of gender as social construct independent from biological reality. The entity doubted the support for the Convention among CoE Member States and stated the "useful" provisions of the document were already well covered by national legislation, but there were a number of "problematic" ones. The opinion contrasted the Convention with the ICC Rome Statute, where "gender" only refers to the two sexes and stated that the subjective nature of gender undermines the predictability of the Convention's norms.

Finally, from a seemingly more political perspective, the monitoring mechanism the document proposes, GREVIO, is claimed to undermine national sovereignty. ${ }^{24}$

\footnotetext{
17 Ibid., p. 53.
}

${ }^{18}$ See the opinion by the Alliance Defending Freedom. National Assembly of the Republic of Bulgaria (2018). Draft Law on the Ratification of the Council of Europe Convention on preventing and combating violence against women and domestic violence (Законопроект за ратифициране на Конвенцията на Съвета на Европа за превенция и борба с насилието над жени и домашното насилие). Retrieved on 28 February 2020, from https://parliament.bg/bg/bills/ID/77944/.

${ }^{19}$ See, for example, National Assembly of the Republic of Bulgaria (2018). Public discussion on the Draft Law on the Ratification of the Council of Europe Convention on preventing and combating violence against women and domestic violence (Обществена дискусия по Законопроекта за ратифициране на Конвенцията на Съвета на Европа за превенция и борба с насилието над жени и домашното насилие). Retrieved on 27 February 2020, from https://parliament.bg/bg/discussion, p. 44-46.

${ }^{20}$ Ibid., p. 56.

${ }^{21}$ Ibid., p. 38, 60 .

22 Ibid., p. 48.

${ }^{23}$ See the opinion by the Alliance Defending Freedom. National Assembly of the Republic of Bulgaria (2018). Draft Law on the Ratification of the Council of Europe Convention on preventing and combating violence against women and domestic violence (Законопроект за ратифициране на Конвенцията на Съвета на Европа за превенция и борба с насилието над жени и домашното насилие). Retrieved on 28 February 2020, from https://parliament.bg/bg/bills/ID/77944/.

24 See, for example, National Assembly of the Republic of Bulgaria. Public discussion on the Draft Law on the Ratification of the Council of Europe Convention on preventing and combating violence against women 
As shown above, the arguments against the ratification of the Convention seem to go along a thin line between law and human rights, politics and religion. They fluctuate among statements like, on the one hand, "contradiction with established legal order", "lack of predictability of legal norms" and, on the other hand, "undermining traditional family values" and "the rights of parents to have the primary responsibility for children's education". (Attempts at) arguments from legal theory and international (human rights) law are mixed with categories about "national sovereignty' and "hidden aims" of a document only "seemingly" countering violence against women.

\subsection{Pro-Convention - institutional effort and NGO campaigns}

On the other end of the spectrum, besides the expressions of political will (see introduction), the Istanbul Convention actually enjoyed, at least on paper, quite wide institutional support.

Pro-Convention opinions were also expressed at the public discussion in the Bulgarian Parliament by the Ombudsman, the British Ambassador, the UNICEF representative to Bulgaria. ${ }^{25}$

Most institutional opinions on the case before the Constitutional Court (see Section 3.3. ${ }^{26}$ showed significant effort on the part of government stakeholders to justify the strive towards ratification and prove the document's constitutionality.

The Minister of Foreign Affairs (who actually signed the Convention in her preceding capacity as Minister of Justice) used international law arguments on interpretation from the Vienna Convention on the Law of Treaties, and from other treaties, to point out that the Convention had nothing to do with regulating marriage, civil status, social security etc., and the definition of gender should be strictly perceived within the context of the act. Moreover, in the realm of national law, it was stated that the notion was already known to Bulgarian law due to its use in the Rome Statute the country had ratified and in acts of the European Union. The opinion also noted that countries had discretion in what measures to undertake to implement the document, while the Convention was in full compliance with the national Constitution's key values - humanity, equality, justice and tolerance, guaranteeing human rights, dignity and security. Moreover, stereotyped gender roles were already known to Bulgaria's legislation on equality between men and women and were profusely looked at in documents like the Convention on the Elimination of all Forms of Discrimination against Women (CEDAW) the country had ratified. Finally, education on gender stereotypes was already postulated in Bulgarian anti-discrimination legislation and is much needed due to the fact that gender stereotypes appear at a very early age. Like the Minister of Foreign Affairs, the Minister of Justice sustained that gender did not replace the notion of sex and only referred to stereotyped roles and models which nurture violence against women. The Minister of Justice stated the Convention did not require the recognition of a "third sex", and its provisions on education basically referred to equality between men and women, respectively boys and girls, while under current Bulgarian Constitution same sex marriages could not be recognized in any case. The State Agency for Child Protection elaborated on the argument that gender had long been part of Bulgarian legislation on equality between men and women and showed with concrete examples that girls were indeed vulnerable to various forms of violence, including alarming statistics on forced marriages. The Agency also pointed out

and domestic violence (Обществена дискусия по Законопроекта за ратифициране на Конвенцията на Съвета на Европа за превенция и борба с насилието над жени и домашното насилие) (2018). Retrieved on 27 February 2020, from https://parliament.bg/bg/discussion, p. 38.

25 Ibid.

${ }^{26}$ Constitutional Court of the Republic of Bulgaria. Case N 3/2018 (Дело № 3/2018 г.) (2018). Retrieved on 28 February 2020, from http://constcourt.bg/bg/Cases/Details/541. 
the gaps in criminalization of domestic violence, the law on protection against domestic violence and its civil protection order procedure and the fact that not all gender-based violence is domestic, therefore the protection, offered by the Convention, is badly needed. The opinion also recalled that gender equality is among the sustainable development goals Bulgaria has committed to uphold and reiterates countries have discretion in shaping its preventive and educational practices in the area.

Parallel to institutional support, NGOs have campaigned continuously in favor of the document. In January 2018, a number of organizations sent an open letter to institutions supporting the actions to ratify the Convention and standing against all statements or interpretations, based on lack of knowledge and will to undertake decisive measures against violence against women. ${ }^{27}$ A number of pro-Convention NGO opinions were expressed at the public discussion in the Bulgarian Parliament, ${ }^{28}$ emphasizing the pervasive nature of domestic violence and the gaps existing in its prevention and counteraction. Aspects outlined were the relationship between domestic violence and violence against children and the fact that violence is not a "family value". ${ }^{29}$ Social workers recalled alarming statistics about women and children killed by acts of domestic and gender-based violence. ${ }^{30}$ Human rights organizations criticized the nontransparent process of preparation of legislative amendments, related to the Convention. ${ }^{31}$ The campaign in favor of the Convention continued via statements before the Constitutional Court. $3^{2}$ The Bulgarian Lawyers for Human Rights defended the Convention along the (constitutional) lines of gender equality, prohibition of discrimination and countering gender-based violence as form of discrimination and stated that gender was only a social role, which was already known to Bulgarian legislation on gender equality, and there was actually no "third sex", as transgender people also identified themselves as men or women. The Animus Association Foundation emphasized on the widespread gender stereotypes among Bulgarians and recalled the CEDAW committee decisions against Bulgaria, criticizing the country on the matter. The Alliance for Protection against Gender-Based Violence noted that the Convention was primarily concerned with violence against women and girls and did not in any way introduce a "third sex". The Alliance reiterated that countries were free in choosing the measures by which to implement the document in domestic legislation and practice and that gender was actually an element of a three-component notion (gender, violence, and women) and not a separate concept related to biological sex. The Alliance also made a detailed, comparative overview of the Convention's English and French texts to explain the notion of gender and cited leading Bulgarian sociologists on the matter to explain that the document did not introduce a "third sex".

\footnotetext{
${ }^{27}$ Alliance for Protection against Gender-Based Violence. Open Letter for Support of the Actions by the Bulgarian State for Ratification of the Istanbul Convention (Отворено писмо за подкрепа на предприетите действия от българската държава за ратифициране на Истанбулската конвенция) (2018). Retrieved on 28 February 2020, from http://www.alliancedv.org/articles/отворенописмо-за-подкрепа-на-предприетите-действия-от-българската-държава-за-ратифициране-наистанбулската-конвенция-конвенция-на-съвета-на-европа-за-превенция-и-борба-с-насилието-наджени-и-домашното-насилие-416.

${ }_{28}$ National Assembly of the Republic of Bulgaria (2018). Public discussion on the Draft Law on the Ratification of the Council of Europe Convention on preventing and combating violence against women and domestic violence (Обществена дискусия по Законопроекта за ратифициране на Конвенцията на Съвета на Европа за превенция и борба с насилието наджени и домашното насилие). Retrieved on 27 February 2020, from https://parliament.bg/bg/discussion.

${ }^{29}$ See, for example, the statement by the Social Activities and Practices Institute, Ibid., p. 34-35.

30 Ibid., p. 52-53.

${ }^{31}$ Ibid., p. 69-70.

$3^{2}$ Constitutional Court of the Republic of Bulgaria (2018). Case N 3/2018 (Дело № 3/2018 2.). Retrieved on 28 February 2020, from http://constcourt.bg/bg/Cases/Details/541.
} 
The campaign in favor of the Convention enjoyed a much wider support by institutions, as well as international backing by ambassadors and intergovernmental organizations. It relied on detailed argumentation from international law and further attempted to show that the norms of the Convention were "foreign" neither to constitutional values, nor to national legislation on equality of men and women and countering discrimination. However, as it will be shown in Section 3.4., statistics on pervasive domestic violence were not sufficient to counter referrals to marriage and family values, while the argument on the primary responsibility of parents to educate their children seemed to overrule the alarming data on early age gender stereotypes, victimization of children by violence and necessity for prevention by education.

It is in this highly divisive and politicized environment that the case about the ratification of the Convention went to its next, and decisive, stage - the review by the country's Constitutional Court.

\subsection{The case before the Constitutional Court}

A case before the Constitutional Court 33 was initiated in February 2018 upon motion by 75 (ruling party) MPs in view of the Convention's impending ratification to assess its compliance with Bulgarian Constitution. In the face of accusations for "passing the hot potato" of rejecting the Convention to the Court, the parliamentarians ${ }^{34}$ cited the deep social divide and fears of recognizing a "third sex" and same-sex marriages as main reasons for motioning the Court. They did mention the nature of "gender" was unknown in Bulgarian legal order, while it was crucial to assess the compliance of the treaty with Bulgarian Constitution. Other than that, the motion actually defended the treaty by inferring from its Articles $3 \mathrm{c}$ and $3 \mathrm{~d}$ ("gender" shall mean the socially constructed roles... a given society considers appropriate for women and men; "genderbased violence against women" shall mean violence that is directed against a woman because she is a woman) that gender only referred to the two sexes. Furthermore, the motion stated the Convention was not an instrument to shape the perception of sex/gender or various ideologies. Nor did it require from states to allow same-sex marriages or recognize a "third sex", which would contradict the Bulgarian Constitution recognizing only marriages between men and women. In the view of the MPs, the case was just the opposite - the Convention called for a gender-based understanding of violence to protect women and girls against such acts.

At the end of July 2018, the Constitutional Court, in an eight to four vote, with four dissenting opinions, came out with a highly criticised decision, proclaiming the Convention unconstitutional. 35 Apart from the multitude of institutional opinions supporting the document (see Section 3.2. on pro-Convention opinions), the President took a critical stance and strictly opposed the document as going "beyond the values of the Bulgarian Constitution", while the Minister of Health tentatively referred to the well-known argument about contradictions between the concepts of sex and gender. Only one NGO deemed the Convention unconstitutional, as well as three law professors, who proclaimed the document unconstitutional and "in conflict with Bulgarian constitutional identity".

In its argumentation, the Court looked at the continuous efforts of the Council of Europe to counter violence against women and the development of international legal regulation

\footnotetext{
33 Ibid.

34 See the Motion by MPs from the $44^{\text {th }}$ National Assembly.

35 Constitutional Court of the Republic of Bulgaria (2018). Decision N 13, Sofia, 27 July 2018, promulgated in SG 65/7 August 2018 (Решение № 13, София, 27 юли 2018 г., обн. ДВ, бр. 65 от о7.08.2018 г.). Retrieved on 28 February 2020, from http://constcourt.bg/bg/Acts/GetHtmlContent/f278a156-9d25412d-a064-6ffd6f997310.
} 
in the area. Parallel to those, and conspicuously similar to the counter-Convention arguments, the Court noted that the Council led a policy against discrimination based on gender identity and in favour of recognising the rights of transgender people. According to the Court, the Convention's main objectives to counter violence against women and domestic violence were in full compliance with Bulgarian Constitution, and pieces of legislation like the Criminal Code, legislation on discrimination and equality between men and women, as well as for protection against domestic violence.

However, again in line with the arguments from the counter-Convention campaign, the document was also found to have internal contradictions which created a "second layer" to its text going outside its declared objectives and name, due to, among others, the interplay between the concepts of sex and gender. On this point, the Court seemed to rely heavily on the main pillars of the sex/gender argumentation and develop it along further lines of discriminatory undertone. Sex and gender, justices noted, were understood through one another to the extent that "gender" could exclude what was biologically determined as male or female - the basis of the "gender ideology", actively debated for more than 20 years throughout Europe. The Court proclaimed the gender dimension counterproductive in protecting women against violence. It stated that the Bulgarian Constitution was based on the binary existence of the human species and what was biologically determined and socially constructed were in actual unity, in contrast to the alleged independence of the "gender". The Rome Statute, equalizing the gender and the two sexes, was also cited.

The Court upheld the binary nature of sex - men and women and stated that biological sex is at the basis of the "civil" sex/gender. The related regulation of marriage and parenthood required clarity, stability and security. Concurring with the counter-Convention campaigners, justices held that the Convention offered protection to people who went outside of what the society determined as "men" or "women" and would oblige Bulgaria to create procedures to recognise "genders" different from the biological sex. Due to the concept of "gender" relativizing the boundaries between the two biological sexes, the scope of the Convention went beyond its proclaimed objectives and opened space for contradictory application. At the same time, the rule of law state required legal security and predictability and would not allow the existence of two parallel, "mutually excluding" concepts, sex and gender. Due to those definitional and procedural problems, the Convention was proclaimed unconstitutional which effectively barred its ratification.

Deep criticism towards the decision was expressed already in the dissenting opinions. Two of the dissenters ${ }^{6}$ noted that, through its acts, the Constitutional Court could not possibly take part into the fight for public support. They reiterated that the Convention is fully compliant with the Constitution's main principles and elaborated that the current notion in the Bulgarian language "sex" (пол) contained all biological, psychological and social aspects of sex/gender. Sexual minorities were in any case protected by legislation, but the Convention did not open doors to recognizing "third" sex or heterosexual/homosexual partnerships. Like the document's supporters, the dissenters noted that gender only referred to the social roles of men and women as the two only sexes and no "third" sex is suggested for recognition. The Convention's norms served only the fight against gender-based violence, while stereotyped gender roles were known already in the Convention on the Elimination of all Forms of Discrimination against Women (CEDAW). Finally, the two justices critically mentioned that the decision's motivation, based on politics and ideology, went beyond the legal analysis required from the Court. Justices feared the "binary" division of men and women may leave intersexual individuals without protection based on gender/sexual identity, condemned the political undertone of the social debate on the Convention and the "service" the Court's decision did to politicians from the whole spectrum.

${ }^{36}$ See dissenting opinion by Justices Nenkov and Angelov. 
M. Ilcheva - Bulgaria and the Istanbul Convention - Law, Politics and Propaganda...

Another justice ${ }^{37}$ noted the negative emotional attitude of society towards the Convention may influence the political decision for its ratification, but not the legal analysis on its compliance with the Constitution.

\subsection{In the aftermath of the Constitutional Court decision}

The Constitutional Court decision came as quite a shock to the civil society and other actors concerned. A number of NGOs came out with a declaration, calling it "humiliating" and "the worst decision in the Court's history". ${ }^{8}$ (Bulgarian-born) European academics criticized the decision as having "peculiar legal arguments and untidy, repetitive narrative". A critical question was posed "if the majority were not influenced by public opinion or even by their personal values since intolerance towards the LGBTI community as well as a stereotypical view of the role of women seem to show through the legal reasoning." 39 However, no new steps have been publicised for possible ratification of the Convention.

In the absence of other options, Bulgaria had to adopt its own, non-Convention based legal amendments. It did so in February 2019, almost a year after the debate on ratifying the Convention and six months after the decision of the Constitutional Court. By amending the Criminal Code, domestic violence was proclaimed aggravating circumstance for murder, incitement towards suicide, bodily injury, kidnapping, illegal deprivation of liberty, coercion, threat to commit a crime against someone. In a special provision, it was defined as systematic physical, sexual, or mental violence, economic dependence, forceful limitation of personal life, freedom and rights against a relative, (ex-)spouse, person with whom the perpetrator has a child, (ex-)co-habitant or person with whom the perpetrator lives or has lived in the same household. The amendments marked the definition and criminalisation of stalking and took a step towards ex officio penalisation of all medium bodily injuries ${ }^{\circ}$ between relatives and spouses, but still left those in a state of vexation (strong irritation) caused by the victim committing violence, serious insult, defamation or another illegal act to be tried upon complaint by the victim. Forced marriages were further criminalised. Whereas non-compliance with domestic violence protection orders and European Protection Orders had been criminalised previously, aggravated punishment for repeated non-compliance was provided for. ${ }^{41}$

37 See dissenting opinion by Justice Penchev.

${ }_{38}^{8}$ Bulgarian Helsinki Committee (2018). Declaration by NGOs on the decision of the Constitutional Court of the Republic of Bulgaria regarding the constitutionality of the Council of Europe Convention on preventing and combating violence against women and domestic violence (Декларация на неправителствени организации по повод решението на Конституционния съд на Република България относно конституционосъобразността на Конвенцията на Съвета на Европа за борба с насилието над жени и домашното насилие). Retrieved on 28 February 2020, from www.bghelsinki.org/bg/novini/press/single/20180727-statement-istanbul-convention/.

39 Vassileva, R. (2018). Bulgaria's constitutional troubles with the Istanbul Convention. Retrieved on 28 February 2020, from https://verfassungsblog.de/bulgarias-constitutional-troubles-with-the-istanbulconvention/.

${ }^{40}$ Lasting weakening of sight or hearing, lasting impairment of speech, movement of limbs, torso or neck, of the functions of sexual organs without causing loss of reproductive capabilities; breaking of a jaw or taking off teeth hindering chewing and speaking; disfigurement of face or other parts of the body; permanent impairment of health, which is not life threatening or impairment of health temporarily threatening life; injuries entering the skull, chest or stomach (Art. 129, para. 2 of the Criminal Code).

${ }^{41}$ National Assembly of the Republic of Bulgaria (2019). Law on Amendments and Supplements to the Criminal Code (Закон за изменение и допълнение на Наказателния кодекс). Retrieved on 29 February 2020, from http://dv.parliament.bg/DVWeb/showMaterialDV.jsp?idMat=134676. 
In the face of Bulgaria's hardening position on the Convention (see introduction), campaigns of similar argumentation ensued, regarding the government's Strategy for the Child 42 and the new draft Law on Social Services. 43 Both documents have significant implications on the protection of victims of gender-based violence. The Strategy puts the prevention and countering of violence and guaranteeing a safe environment and access to justice for every child among its strategic aims and provides for support and protection of children in contact with the justice system. The social services law offers specific regulation on (urgently) placing victims of domestic violence and trafficking into social services.

However, a circle of organizations similar to the one having rejected the Istanbul Convention 44 and using similar argumentation, criticized the Strategy as limiting the rights of parents and providing for an "undemocratic" widening of the functions of the state towards children and family life. The Strategy was allegedly violating a number of fundamental rights regulated in the ECHR. The state was claimed to be able to take away and institutionalize children just because of the poverty of their families and the physical disciplining of children "with restraint for educational purposes", which the Strategy rejected, was claimed to be a legitimate method. Thus, the Strategy allegedly violated people's right to personal and family life, while no mechanisms existed for controlling officials' activity. As regards the Law on Social Services, 45 social service providers and NGOs ardently opposed the statements that the new law opened the door for "private entities" to provide social services in Bulgaria saying that they had been doing so for more than 10 years already. NGOs also denied that some "ill-meaning" organizations would enter the country and create problems for children and families.

As a result of the campaigns, the Strategy was subsequently withdrawn, while the law's entry into force was delayed by (initially) half a year.

One of the latest campaigns against de facto gender-based violence-oriented measures concerned a program for prevention of sexual assault against children. ${ }^{46}$ The campaign potentially stifled the effort to introduce such programs on a regular and sustainable basis as part of the school curricula.

Clearly motivated by recent campaigns, the State Agency for Child Protection announced its decision to take away the national children's helpline from a long time NGO service provider and manage it itself, again through public procurement. ${ }^{47}$

${ }^{42}$ Council of Ministers of the Republic of Bulgaria (2019). Draft National Strategy for the Child 2019-203O (Проект на Национална стратегия за детето 2019-2030 2.). Retrieved on 29 February 2020, from www.strategy.bg/PublicConsultations/View.aspx?lang=bg-BG\&Id=4012.

43 Law on Social Services (Закон за социалните услуги) (2020). Retrieved on 29 February 2020, from https://www.lex.bg/bg/laws/ldoc/2137191914.

44 See, for example, Freedom for Everyone (2019). Opinion on the National Strategy for the Child 20192030 (Становище относно Национална стратегия за детето 2019-203о 2.). Retrieved on 29 February 2020, from https://svobodazavseki.com/blog/item/327-stanovishte-sv-strategia-20192030.html.

45 See, for example, the Open Letter about the intentions of delaying the entry into force of the Law on Social Services (ОТВОРЕНО ПИСМО относно: Намеренията за отлагането на влизането в сила на Закона за социалните услуги) (2019). Retrieved on 29 February 2020, from https://nmd.bg/wpcontent/uploads/2019/12/otvoreno-pismo-ot-56-grajdanski-organizacii-1.pdf.

${ }^{46}$ Marginalia bg (2020). PULSE psychologists: We are subjected to an anti-legal and anti-human 'people's' policy (Психолозите от П.У.Л.С - Подложени сме на антиправова и антихуманна „народна” политика). Retrieved on 28 February 2020, from https://www.marginalia.bg/tag/programa-taralezhi/.

47 NGObg.info (2020). The State Agency for Child Protection undertakes the management of the National Children's Helpline 116111 (ДАЗД поема управлението на Националната телефонна линия за деца 116 111). Retrieved on 28 February 2020, from https://www.ngobg.info/bg/news/119767- 
4. Bulgaria's fight against gender-based violence - Current status

After clearly influencing the Constitutional Court decision for rejecting the Istanbul Convention as unconstitutional, campaigns against anti-violence legislation, strategies and social services continue in Bulgaria in an environment of systematic problems in countering genderbased violence in most of the areas the Convention covers.

Having until recently only a civil protection procedure, whose effectiveness is often debated, ${ }^{48}$ Bulgaria, as seen in Section 3.4., criminalized domestic violence belatedly and in a highly criticized manner. Prominent organisations have submitted numerous statements, regarding legislative gaps and weaknesses the amendments attempted to address only partially. In particular, organisations have insisted 49 that all forms of domestic violence that led to bodily injury shall be prosecuted ex officio, in harmony with the Istanbul Convention and the CEDAW committee recommendations to Bulgaria of 2012,50 which has still not become reality. The specific criminalisation of strangling and marital rape, as an aggravated case of rape, has also been proposed, and has still not been adopted. Experts have criticised recent Criminal Code amendments as only criminalising systematic violence (committed more than three times) and offering partial protection to victims of crimes between relatives by still not penalizing ex officio all such crimes. ${ }^{11}$ Furthermore, no clarity exists yet as to how civil law protection measures will combine with protection measures in the criminal process, if both types of proceedings are opened for acts of domestic violence.

A number of proceedings against Bulgaria before the Committee on the Elimination of Discrimination against Women (CEDAW) have also yielded recommendations towards the country's domestic violence protection system..$^{2}$ The country has shown notorious defects in its

\%Do\%B4\%Do\%Bo\%Do\%B7\%Do\%B4-\%Do\%BF\%Do\%BE\%Do\%B5\%Do\%BC\%Do\%Bo\%D1\%83\%Do\%BF\%D1\%80\%Do\%Bo\%Do\%B2\%Do\%BB\%Do\%B5\%Do\%BD\%Do\%B8\%Do\%B5\%D1\%82\% Do\%BE-\%Do\%BD\%Do\%Bo-

\%Do\%BD\%Do\%Bo\%D1\%86\%Do\%B8\%Do\%BE\%Do\%BD\%Do\%Bo\%Do\%BB\%Do\%BD\%Do\%Bo\%D1\%82 \%Do\%Bo-\%D1\%82\%Do\%B5\%Do\%BB\%Do\%B5\%D1\%84\%Do\%BE\%Do\%BD\%Do\%BD\%Do\%Bo\%Do\%BB\%Do\%B8\%Do\%BD\%Do\%B8\%D1\%8F-\%Do\%B7\%Do\%Bo\%Do\%B4\%Do\%B5\%D1\%86\%Do\%Bo-116-111.html.

${ }^{48}$ See, for example, PULSE Foundation (2016). Monitoring report on challenges and good practices in implementing the Law on Protection against Domestic Violence in the South-West Region (МОНИТОРИНГОВ ДОКЛАД Предизвикателства и добри практики в прилагането на Закона за защита от домашното насилие в Югозападен регион). Retrieved on 29 February 2020, from https://www.pulsfoundation.org/images/biblio/Monitoringow-doklad.pdf.

49 Alliance for Protection against Gender-Based Violence (2014). Proposals on the draft Criminal Code, related to sexual violence and gender-based violence (Предложения по Проекта на Наказателния кодекс свързани със сексуалното насилие и насилието, основано на пола). Retrieved on 29 February 2020, from http://www.alliancedv.org/articles/.

${ }^{\circ}$ Committee on the Elimination of Discrimination against Women (2012). Concluding observations of the Committee on the Elimination of Discrimination against Women, Bulgaria. New York: Committee on the Elimination of Discrimination against Women.

${ }^{51}$ See more in Berbec, S. et al. (2019). Violence against women: Key findings and strategies to tackle unreported cases and to enforce the protection order. Retrieved on 29 February 2020, from https://csd.bg/fileadmin/user_upload/publications_library/files/2019_04/Study_Report_EN_Justice_f or Women.pdf.

$5^{2}$ Committee on the Elimination of Discrimination against Women (2011). Views Communication No. 20/2008 (Forty-ninth session 11-29 July 2011) CEDAW/C/49/D/20/2008; Committee on the Elimination of Discrimination against Women (2012). Communication No. 32/2011 Views adopted by the Committee at its fifty-second session, 9-27 July 2012 (Fifty-second session 9-27 July 2012) CEDAW/C/52/D/32/2011. 
system of investigation and prosecution of violence (against women), profoundly criticized before the European Court of Human Rights. 53

Apart from ad hoc project based activities 54 and studies, 55 there has been no consistent effort to prevent, counter, or tackle the consequences of preceding gender-based violence among asylum seeking and migrant populations. According to the reports of the National Anti-Trafficking Commission, no foreign victims of human trafficking, as an utmost form of gender-based violence, have been identified yet. Doubts would arise as to whether the existing services would be able to timely adapt to the specific needs of migrant populations, such as language barrier, cultural specifics, etc.

In terms of comprehensive and coordinated policies, as required by the Convention, Bulgaria has a co-ordination mechanism for helping and supporting victims of domestic violence, ${ }^{6}$ but its adoption has been for a long time stalled due to various institutional hindrances, mainly on the part of the Ministry of Health. The National Programmes for Prevention and Protection against Domestic Violence 57 aim at a coordinated effort among institutions in fighting the phenomenon of domestic (and gender-based) violence, but rather contain a set of institutional measures some of which achieve no or just partial implementation and pass from program to program for many years. The Ministry of the Interior has a national coordinator on domestic violence, but no coordinating body exists for the policies at interinstitutional level.

Problems have persisted in the collection of data on acts of domestic violence. The de facto existence of two parallel, civil and criminal procedure protection, regimes against such acts is expected to deepen those problems. Underfinancing has for many years limited the abilities of victim service providers to ensure adequate protection and support for victims throughout the country. Measures to develop risk assessment and risk management mechanisms for police authorities in tackling cases of domestic violence have only started to be developed.

\footnotetext{
53 See, for example, CASE OF Y v. BULGARIA (Application no. 41990/18). Retrieved on 29 February 2020, from http://hudoc.echr.coe.int/eng?i=001-201350 and CASE OF S.Z. v. BULGARIA (Application no. 29263/12). Retrieved on 29 February 2020, from http://hudoc.echr.coe.int/eng?i=001-152850.

54 IOM Bulgaria (2018). PROTECT - Preventing sexual and gender-based violence against migrants and strengthening support to victims. Retrieved on 29 February 2020, from http://iom.bg/bg/content/\%Do\%BF\%D1\%80\%Do\%BE\%D1\%82\%Do\%B5\%Do\%BA\%D1\%82.

55 Tisheva, G., \& Nikolova, A. (2015). Monitoring report on sexual and gender-based violence (Мониторингов доклад за сексуално и свързано с пола насилие). Retrieved on 29 February 2020, from http://bgrf.org/articles/\%Do\%BC\%Do\%BE\%Do\%BD\%Do\%B8\%D1\%82\%Do\%BE\%D1\%80\%Do\%B8\%Do \%BD\%Do\%B3\%Do\%BE\%Do\%B2-\%Do\%B4\%Do\%BE\%Do\%BA\%Do\%BB\%Do\%Bo\%Do\%B4-

\%Do\%B7\%Do\%Bo-\%D1\%81\%Do\%B5\%Do\%BA\%D1\%81\%D1\%83\%Do\%Bo\%Do\%BB\%Do\%BD\%Do\%BE\%Do\%B8-\%D1\%81\%Do\%B2\%D1\%8A\%D1\%80\%Do\%B7\%Do\%Bo\%Do\%BD\%Do\%BE-\%D1\%81\%Do\%BF\%Do\%BE\%Do\%BB\%Do\%Bo\%Do\%BD\%Do\%Bo\%D1\%81\%Do\%B8\%Do\%BB\%Do\%B8\%Do\%B5-495.

${ }^{6}$ See Animus Association Foundation (2017). Co-ordination mechanism on helping and supporting victims of domestic violence (Координационен механизъм за помощ и подкрепа на пострадали от домашно насилие). Retrieved on 29 February 2020, from http://animusassociation.org/wpcontent/uploads/2017/08/Koordinacionen-mehanizum-doma6no-nasilie.pdf.

57 Council of Ministers of the Republic of Bulgaria (2019). National Programme for Prevention and Protection against Domestic Violence for 2019 (Национална програма за превенция и защита от домашно насилие за 2019 г.). Retrieved on 29 February 2020, from http://www.strategy.bg/StrategicDocuments/View.aspx?lang=bg-BG\&Id=1274.
} 


\section{Campaign's potential consequences}

Civil society and victim protection stakeholders still ponder on the harm caused by the propaganda campaign against the Istanbul Convention on the overall protection of victims of domestic and gender-based violence in Bulgaria. Although a direct link between the campaign and subsequent developments could hardly be claimed, and proven, in the view of the present article, the harmful consequences of the "anti-Convention movement" should be sought in several main directions. Those are important to be publicized at a European level to provide "lessons learned" for other countries in Europe and beyond struggling to provide better protection for populations victimized by gender-based violence.

The campaign has decisively influenced the decision of the Constitutional Court, which in turn has so far brought the strive to ratify the Convention to a definitive end. Although far from unknown in Europe and other continents, $5^{8}$ the anti-gender movement in Bulgaria has been among the ones having impacted the functioning of a state on the highest level by influencing a decision of paramount importance. The Court almost uncritically, and with a discriminatory undertone against transgender populations and other vulnerable groups, concurred with the movement's arguments about the dangerous nature of the interplay between sex and gender. The notions of "gender ideology" and "third sex" easily found its way in the elaborations of Bulgaria's constitutional jurisdiction and no reliance was made on other institutions' detailed statements on the Convention's compliance with the Constitution, and indicative statistics on the spread of gender-based violence and gender stereotyping. The same goes for the recurring anti-gender argument that the document has legitimate aims, but also a "second layer" which does not actually prevent and protect women from violence. Moreover, vulnerable groups like transgender people, the "binary" nature of sex and relatively rigidly regulated concepts like marriage and parenthood were referred to in a manner practically discriminating anybody who would deviate from the "norm". No practical reference was made to the pieces of Bulgarian legislation touching upon the notion of gender, or of the substantial gaps the country's legislation exhibits in countering the phenomenon of gender-based violence.

Secondly, by upholding "family values" and standing against "ill-meaning foreign influence" the movement paved the way for subsequent campaigns against documents of utmost importance for victims of crime, and in particular gender-based violence. The National Strategy for the Child and the Law on Social Services regulate critical aspects of victims' protection - the protection of the most vulnerable among the victims, children, and the support given to them by social services. Thus, the series of campaigns substantially undermined the holistic approach the Istanbul Convention advocates for in protecting and supporting victims of domestic and genderbased violence. Moreover, by directly attacking the work of NGOs and leading to, among others, re-assigning the management of crucial services like the national children's helpline, the campaigns almost stifled the activity of major actors in the ecosystem for protecting victims. As organizations, countering gender-based violence, including human trafficking, represent a substantial part of the victim support and service provider actors in Bulgaria, this movement has had negative consequences on the overall protection of all victims in the country and the traditional stance of Bulgaria not questioning "the universality of the rights of crime victims" and treating them as "an inherent part of human rights".59

58 Corrêa, S., Paternotte, D., \& Kuhar, R. (2018). The globalization of anti-gender campaigns: Transnational anti-gender movements in Europe and Latin America create unlikely alliances. Retrieved on 29 February 2020, from https://www.ips-journal.eu/topics/human-rights/article/show/theglobalisation-of-anti-gender-campaigns-2761/.

59 Chankova, D., \& Andonova, S. (2012). Contemporary policies and practices towards crime victims in Bulgaria: Are we still beyond time? Postmodernism Problems, 2(2), 71-86. 
Thirdly, the campaign against and subsequent refusal to ratify the Istanbul Convention critically delayed and hindered the adoption of effective and adequate national legislation to practically implement the Convention's norms. Besides rather fragmented Criminal Code amendments (see Section 3.4.), as admitted at the earliest stages of ratification effort, the country needs urgent amendments in its legislation on domestic violence and victim support and protection within criminal and civil procedure. Amendments are claimed to be prepared by public authorities, but they are still not available in the public domain even in draft and the drastically lowered quality of public debate has not allowed to voice a strong public demand of such urgent changes in law.

Last but not least, by influencing the Constitutional Court decision and Bulgaria's subsequent negative positions on the Convention on EU level, the campaign does have the potential to substantially delay and hinder the EU wide adoption and implementation of the document. This may critically undermine the cooperation among states on Union and also on regional level in preventing and countering the phenomenon of gender-based violence and the EU wide protection victims should receive.

\section{Conclusions and the road ahead}

No apparent solutions have been publicized so far regarding the unconstitutionality ruling the Bulgarian Constitutional Court on the Istanbul Convention. The campaign against the document has not been renewed, but has continued with similar argumentation against various steps in the social and educational sphere, presented as undue foreign influence. Legislative drafting to further transpose Directive 2012/29/EU of the European Parliament and of the Council of 25 October 2012 establishing minimum standards on the rights, support and protection of victims of crime, and replacing Council Framework Decision 2001/220/JHA in Bulgarian legislation is allegedly underway, as well amendments in the civil legislation on domestic violence, but actual adoption of amendments has got no further than the Criminal Code amendments discussed in Section 3.4. Cases under the amended provisions are instituted, but prosecution and law enforcement experience significant difficulties, regarding proving the domestic violence and eliciting the testimony of victims. ${ }^{60}$

Thus, apart from urgent legislative amendments, which should be demanded via political and civic channels, criminal justice authorities and victim service providers have small to none legislative leeway to work towards improving the processing of gender-violence cases. Instead, practical improvements should be sought - use of various means to prove (systematic) domestic violence in criminal cases, as well as better observance of civil protection orders. The coordination mechanism on victims of domestic violence, discussed in section 4, should ultimately be adopted and rigorously applied to ensure no case falls through the gaps of interinstitutional cooperation.

Finally, avenues should be sought to influence domestic legislature through the process of EU accession to the Convention. Other international channels should also be explored, such as the recent critical stance by the UN Special Rapporteur on violence against women, its causes and consequences, who demanded the reopening of the ratification process for the Convention. ${ }^{61}$ Even if no way out is found of the unconstitutionality pronouncement, decisive

6o Center for the Study of Democracy (2019). Protection of women victims of crime. Retrieved on 29 February 2020, from https://csd.bg/events/event/protection-of-women-victims-of-crime/.

${ }^{61}$ The Office of the High Commissioner for Human Rights (2019). Bulgaria: UN expert concerned about pushbacks on women's rights and misinterpretation of the term "gender" that stopped the ratification of the Istanbul Convention. Retrieved on 1 March 2020, from https://www.ohchr.org/en/NewsEvents/Pages/DisplayNews.aspx?NewsID=25178\&LangID=E. 
legislative and practical steps should be taken for a de facto ratification of the document to ensure strong and consistent protection and support of victims of gender-based violence and, ultimately, all victims of violence through improved investigation, prosecution and service provision.

\section{Acknowledgements}

This research did not receive any specific grant from funding agencies in the public commercial, or not-for-profit sectors.

The author declares no competing interests.

\section{References}

Alliance for Protection against Gender-Based Violence (2014). Proposals on the draft Criminal Code, related to sexual violence and gender-based violence (Предложения по Проекта на Наказателния кодекс свързани със сексуалното насилие и насилието, основано на пола). Retrieved on 29 February 2020, from http://www.alliancedv.org/articles/

Alliance for Protection against Gender-Based Violence (2018). Open letter for support of the actions by the Bulgarian State for ratification of the Istanbul Convention (Отворено писмо за подкрепа на предприетите действия от българската държава за ратифициране на Истанбулската конвенция). Retrieved on 28 February 2020, from http://www.alliancedv.org/articles/отворено-писмо-за-подкрепа-на-предприетитедействия-от-българската-държава-за-ратифициране-на-истанбулската-конвенцияконвенция-на-съвета-на-европа-за-превенция-и-борба-с-насилието-над-жени-идомашното-насилие-416.

Animus Association Foundation (2017). Co-ordination mechanism on helping and supporting victims of domestic violence (Координационен механизъм за помощ и подкрепа на пострадали от домашно насилие). Retrieved on 29 February 2020, from http://animusassociation.org/wpcontent/uploads/2017/08/Koordinacionen-mehanizum-doma6no-nasilie.pdf.

Berbec, S. et al. (2019). Violence against women: Key findings and strategies to tackle unreported cases and to enforce the protection order. Retrieved on 29 February 2020, from https://csd.bg/fileadmin/user_upload/publications_library/files/2019_04/Study_Report_E $\mathrm{N}$ Justice for Women.pdf.

Bulgarian Gender Research Foundation (2016). Bulgaria signed the Council of Europe Convention on preventing and combating violence against women and domestic violence (Istanbul Convention) (България подписа Конвенцията на Съвета на Европа за превенция и борба с насилието срещу жени и домашното насилие (Истанбулската конвенция)). Retrieved $27 \quad$ February $2020, \quad$ from http://bgrf.org/articles/\%Do\%B1\%D1\%8A\%Do\%BB\%Do\%B3\%Do\%Bo\%D1\%80\%Do\%B8\% D1\%8F-\%Do\%BF\%Do\%BE\%Do\%B4\%Do\%BF\%Do\%B8\%D1\%81\%Do\%Bo\%Do\%BA\%Do\%BE\%Do\%BD\%Do\%B2\%Do\%B5\%Do\%BD\%D1\%86\%Do\%B8\%D1\%8F\%D1\% 82\%Do\%Bo-\%Do\%BD\%Do\%Bo-\%D1\%81\%D1\%8A\%Do\%B2\%Do\%B5\%D1\%82\%Do\%Bo\%Do\%BD\%Do\%Bo-\%Do\%B5\%Do\%B2\%D1\%80\%Do\%BE\%Do\%BF\%Do\%Bo\%Do\%B7\%Do\%Bo\%Do\%BF\%D1\%80\%Do\%B5\%Do\%B2\%Do\%B5\%Do\%BD\%D1\%86\%Do\%B8\%D1\%8F\%Do\%B8-\%Do\%B1\%Do\%BE\%D1\%80\%Do\%B1\%Do\%Bo-\%D1\%81\%Do\%BD\%Do\%Bo\%D1\%81\%Do\%B8\%Do\%BB\%Do\%B8\%Do\%B5\%D1\%82\%Do\%BE\%D1\%81\%D1\%80\%D0\%B5\%D1\%89\%D1\%83-\%Do\%B6\%Do\%B5\%Do\%BD\%Do\%B8- 
\%Do\%B8-

\%Do\%B4\%Do\%BE\%Do\%BC\%Do\%Bo\%D1\%88\%Do\%BD\%Do\%BE\%D1\%82\%Do\%BE-

\%Do\%BD\%Do\%Bo\%D1\%81\%Do\%B8\%Do\%BB\%Do\%B8\%Do\%B5-

\%Do\%B8\%D1\%81\%D1\%82\%Do\%Bo\%Do\%BD\%Do\%B1\%D1\%83\%Do\%BB\%D1\%81\%Do\%BA

\%Do\%Bo\%D1\%82\%Do\%Bo-

\%Do\%BA\%Do\%BE\%Do\%BD\%Do\%B2\%Do\%B5\%Do\%BD\%D1\%86\%Do\%B8\%D1\%8F-507

Bulgarian Helsinki Committee (2018). Declaration by NGOs on the decision of the Constitutional Court of the Republic of Bulgaria regarding the constitutionality of the Council of Europe Convention on preventing and combating violence against women and domestic violence (Декларация на неправителствени организации по повод решението на Конституционния съд на Република България относно конституционосъобразността на Конвенцията на Съвета на Европа за борба с насилието наджени и домашното насилие). Retrieved on 28 February 2020, from www.bghelsinki.org/bg/novini/press/single/20180727-statementistanbul-convention/.

Bulgarian Socialist Party (2018). Kornelia Ninova: When people say "No" to the Istanbul Convention, this chapter will be closed forever (Корнелия Нинова: Когато хората кажат "не" на Истанбулската конвенция, въпросът се затваря завинаги). Retrieved 28 February 2020, from http://bsp.bg/news/view/13815-

korneliya ninova kogato horata kajat ne na istanbulskata konventsiya vyprosyt se zatvarya zavinagi.html.

Center for the Study of Democracy (2019). Protection of women victims of crime. Retrieved on 29 February 2020, from https://csd.bg/events/event/protection-of-women-victims-of-crime/

Chankova, D., \& Andonova, S. (2012). Contemporary policies and practices towards crime victims in Bulgaria: Are we still beyond time? Postmodernism Problems, 2(2), 71-86.

Committee on the Elimination of Discrimination against Women (2011). Views Communication No. 20/2008 (Forty-ninth session 11-29 July 2011) CEDAW/C/49/D/20/2008.

Committee on the Elimination of Discrimination against Women (2012). Communication No. 32/2011 Views adopted by the Committee at its fifty-second session, 9-27 July 2012 (Fifty-second session 9-27 July 2012) CEDAW/C/52/D/32/2011.

Committee on the Elimination of Discrimination against Women (2012). Concluding observations of the Committee on the Elimination of Discrimination against Women, Bulgaria. New York: Committee on the Elimination of Discrimination against Women.

Constitutional Court of the Republic of Bulgaria (2018a). Case N 3/2018 (Дело № 3/2018 2.). Retrieved on 28 February 2020, from http://constcourt.bg/bg/Cases/Details/541.

Constitutional Court of the Republic of Bulgaria (2018b). Decision No 13, Sofia, 27 July 2018, promulgated SG issue 65/7 August 2018 (Решение № 13, София, 27 юли 2018 г., (обн., ДВ, бр. 65 от 07.08.2018 2.)). $\quad$ Retrieved $27 \quad$ February 2020, from http://constcourt.bg/bg/Acts/GetHtmlContent/f278a156-9d25-412d-a064-6ffd6f997310.

Corrêa, S., Paternotte, D., \& Kuhar, R. (2018). The globalisation of anti-gender campaigns: Transnational anti-gender movements in Europe and Latin America create unlikely alliances. Retrieved on 29 February 2020, from https://www.ips-journal.eu/topics/human-rights/article/show/theglobalisation-of-anti-gender-campaigns-2761/.

Council of Europe (2016). Bulgaria signs the Istanbul Convention. Retrieved on 27 February 2020, from https://www.coe.int/en/web/istanbul-convention/newsroom/-

Lasset publisher/anlInZ5mw6yX/content/bulgaria-signs-the-istanbulconvention?inheritRedirect $=$ false.

Council of Ministers of the Republic of Bulgaria (2018). Agenda of the Council of Ministers session of 3 Jапиату 2018 (Дневен ред на заседанието на Министерския съвет на 03.01.2018 2.). Retrieved on 27 February 2020, from https://government.bg/bg/prestsentar/zasedaniya-na$\mathrm{ms} /$ dneven-red-na-zasedanieto-na-ministerskiya-savet-na-03-01-2018-g. 
M. Ilcheva - Bulgaria and the Istanbul Convention - Law, Politics and Propaganda...

Council of Ministers of the Republic of Bulgaria (2019a). Agenda of the Council of Ministers session of 11 December 2019 (Дневен ред на заседанието на Министерския съвет на 11.12.2019 г.). Retrieved on 27 February 2020, from https://government.bg/bg/prestsentar/zasedaniya-nams/dneven-red-na-zasedanieto-na-ministerskiya-savet-na-11-12-2019-g.

Council of Ministers of the Republic of Bulgaria (2019b). Draft National Strategy for the Child 2019-203O (Проект на Национална стратегия за детето 2019-203о 2.). Retrieved on 29 February 2020, from www.strategy.bg/PublicConsultations/View.aspx?lang=bg-BG\&Id=4012.

Council of Ministers of the Republic of Bulgaria (2019c). National Programme for Prevention and Protection against Domestic Violence for 2019 (Национална програма за превенция и защита от домашно насилие за 2019 г.). Retrieved on 29 February 2020, from http://www.strategy.bg/StrategicDocuments/View.aspx?lang=bg-BG\&Id=1274.

Court of Justice of the European Union (2019). Request for an opinion submitted by the European Parliament pursuant to Article 218(11) TFEU. Retrieved on 27 February, from http://curia.europa.eu/juris/document/document.jsf;jsessionid=2BC30754500BC2A3CFF3 $\underline{\text { F47B03Do0157?text }=\& \text { docid }=221362 \& \text { pageIndex }=0 \& \text { doclang }=\text { EN\&mode }=1 \text { st\&dir }=\& o c c=\text { firs }}$ t\&part $=1 \&$ cid $=6150317$.

European Court of Human Rights (2018). CASE OF Y v. BULGARIA (Application no. 41990/18). Retrieved on 29 February 2020, from http://hudoc.echr.coe.int/eng?i=001-201350.

European Court of Human Rights (2012). CASE OF S.Z. v. BULGARIA (Application no. 29263/12). Retrieved on 29 February 2020, from http://hudoc.echr.coe.int/eng?i=001-152850.

European Parliament (2019). EU accession to the Istanbul Convention and other measures to combat gender-based violence. Retrieved on 27 February 2020, from https://www.europarl.europa.eu/doceo/document/TA-9-2019-0080 EN.html.

Freedom for Everyone (2019). Opinion on the National Strategy for the Child 2019-203о (Становище относно Национална стратегия за детето 2019-203о г.). Retrieved on 29 February 2020, from https://svobodazavseki.com/blog/item/327-stanovishte-sv-strategia-20192030.html.

IOM Bulgaria. (2018) PROTECT - Preventing sexual and gender-based violence against migrants and strengthening support to victims. Retrieved on 29 February 2020, from http://iom.bg/bg/content/\%Do\%BF\%D1\%80\%Do\%BE\%D1\%82\%Do\%B5\%Do\%BA\%D1\%82

Law on Social Services (Закон за социалните услуги) (2020). Retrieved on 29 February 2020, from https://www.lex.bg/bg/laws/ldoc/2137191914.

Marginalia bg (2020). PULSE psychologists: We are subjected to an anti-legal and anti-human 'people's' policy (Психолозите от П.У.Л.С - Подложени сме на антиправова и антихуманна „народна" политика). Retrieved on 28 February 2020, from https://www.marginalia.bg/tag/programa-taralezhi/.

Ministry of Justice of the Republic of Bulgaria (2017). Deputy Minister Ahladova: Bulgaria is going to ratify the Istanbul Convention (Зам.-министър Ахладова: България ще ратифицира Истанбулската конвенция). Retrieved on 27 February 2020, from https://webcache.googleusercontent.com/search?q=cache:cvGgejfLNpEJ:https://justice.gov ernment.bg/117/13759/+\&cd =1\&hl=en\&ct=clnk\&gl=bg.

National Assembly of the Republic of Bulgaria (2018a). Public discussion on the Draft Law on the Ratification of the Council of Europe Convention on preventing and combating violence against women and domestic violence (Обществена дискусия по Законопроекта за ратифициране на Конвенцията на Съвета на Европа за превенция и борба с насилието над жени и домашното насилие). Retrieved on 27 February 2020, from https://parliament.bg/bg/discussion.

National Assembly of the Republic of Bulgaria (2018b). Draft Law on the Ratification of the Council of Europe Convention on preventing and combating violence against women and domestic violence (Законопроект за ратифициране на Конвенцията на Съвета на Европа за 
превенция и борба с насилието над жени и домашното насилие). Retrieved on 28 February 2020, from https://parliament.bg/bg/bills/ID/77944/.

National Assembly of the Republic of Bulgaria (2019). Law on Amendments and Supplements to the Criminal Code (Закон за изменение и допълнение на Наказателния кодекс). Retrieved on 29 February 2020, from http://dv.parliament.bg/DVWeb/showMaterialDV.jsp?idMat=134676.

NGObg.info (2020). The State Agency for Child Protection undertakes the management of the National Children's Helpline 116111 (ДАЗД поема управлението на Националната телефонна линия за деца 116 111). Retrieved on 28 February 2020, from https://www.ngobg.info/bg/news/119767-\%Do\%B4\%Do\%Bo\%Do\%B7\%Do\%B4\%Do\%BF\%Do\%BE\%Do\%B5\%Do\%BC\%Do\%Bo\%D1\%83\%Do\%BF\%D1\%80\%Do\%Bo\%Do\%B2\%Do\%BB\%Do\%B5\%Do\%BD\%Do\%B8\%Do\% B5\%D1\%82\%Do\%BE-\%Do\%BD\%Do\%Bo\%Do\%BD\%Do\%Bo\%D1\%86\%Do\%B8\%Do\%BE\%Do\%BD\%Do\%Bo\%Do\%BB\%Do\%BD\%Do \%Bo\%D1\%82\%Do\%Bo\%D1\%82\%Do\%B5\%Do\%BB\%Do\%B5\%D1\%84\%Do\%BE\%Do\%BD\%Do\%BD\%Do\%Bo\%Do\%BB\%Do\%B8\%Do\%BD\%Do\%B8\%D1\%8F-\%Do\%B7\%Do\%Bo\%Do\%B4\%Do\%B5\%D1\%86\%Do\%Bo-116-111.html.

Open Letter about the intentions of delaying the entry into force of the Law on Social Services (OTBOPEHO ПИСМО относно: Намеренията за отлагането на влизането в сила на Закона за социалните услуги) (2019). Retrieved on 29 February 2020, from https://nmd.bg/wpcontent/uploads/2019/12/otvoreno-pismo-ot-56-grajdanski-organizacii-1.pdf.

Office of the High Commissioner for Human Rights (2019). Bulgaria: UN expert concerned about pushbacks on women's rights and misinterpretation of the term "gender" that stopped the ratification of the Istanbul Convention. Retrieved on 1 March 2020, from https://www.ohchr.org/en/NewsEvents/Pages/DisplayNews.aspx?NewsID=25178\&LangID= E.

PULSE Foundation (2016). Monitoring report on challenges and good practices in implementing the Law on Protection against Domestic Violence in the South-West Region (МОНИТОРИНГОВ ДОКЛАД Предизвикателства и добри практики в прилагането на Закона за защита от домашното насилие в Югозападен регион). Retrieved on 29 February 2020, from https://www.pulsfoundation.org/images/biblio/Monitoringow-doklad.pdf.

Tisheva, G., \& Nikolova, A. (2015). Monitoring report on sexual and gender-based violence (Мониторингов доклад за сексуално и свързано с пола насилие). Retrieved on 29 February 2020, from http://bgrf.org/articles/\%Do\%BC\%Do\%BE\%Do\%BD\%Do\%B8\%D1\%82\%Do\%BE\%D1\%80\% Do\%B8\%Do\%BD\%Do\%B3\%Do\%BE\%Do\%B2\%Do\%B4\%Do\%BE\%Do\%BA\%Do\%BB\%Do\%Bo\%Do\%B4-\%Do\%B7\%Do\%Bo\%D1\%81\%Do\%B5\%D0\%BA\%D1\%81\%D1\%83\%Do\%Bo\%Do\%BB\%Do\%BD\%Do\%BE\%Do\%B8-\%D1\%81\%Do\%B2\%D1\%8A\%D1\%80\%Do\%B7\%Do\%Bo\%Do\%BD\%Do\%BE\%D1\%81-\%Do\%BF\%Do\%BE\%Do\%BB\%Do\%Bo\%Do\%BD\%Do\%Bo\%D1\%81\%Do\%B8\%Do\%BB\%Do\%B8\%Do\%B5-495.

Vassileva, R. (2018). Bulgaria's constitutional troubles with the Istanbul Convention. Retrieved on 28 February 2020, from https://verfassungsblog.de/bulgarias-constitutional-troubles-with-theistanbul-convention/. 
M. Ilcheva - Bulgaria and the Istanbul Convention - Law, Politics and Propaganda...

C O A $\mathbf{s}$ 